\title{
ALCOHOL AND THE WAR: THE ACTION OF OUR ALLIES.
}

\section{BY JOHN NEWTON.}

SINCE the publication of the January issue of this Journal, in which appeared an article explaining the action which Russia has taken in regard to alcohol, much additional evidence has become available concerning this remarkable step of the Russian Government in prohibiting the sale of vodka and other spirits as a war measure, and as to the effects of that action upon the people at large.

France has recently followed Russia's example, and has enacted prohibition of absinthe, the most deadly of all alcoholic beverages. Thousands of earnest, patriotic citizens in this country are asking--When will Britain follow the noble example of her Allies, make a similar sacrifice for the sake of efficiency in the war, and suppress, at least for the war period, the manufacture and sale of ardent spirits?

\section{THE ACTION OF RUSSIA.}

The British Ambassador at Petrograd has forwarded a Memorandum on the action of the Russian Government, which has been issued by our Foreign Office. The following quotations from the Memorandum give the most salient points : "With the publication of the order for a general mobilization of the land and sea forces of the Empire, all wine-shops, beer-saloons, and Government vodka shops, were closed, and the sale of all intoxicants absolutely prohibited, except in first-class restaurants and hotels, until completion of mobilization. This order, with varying modifications, has been prolonged from time to time, and remains in force at the present moment. By an order of the Council of Ministers, published September 3-16, it was notified that His Imperial Majesty had been pleased, on August 22-September 4,* to

"So printed in the Memorandum, presumably to show the difference between the Gregorian and Julian Calendars. 
prohibit the sale of spirits and vodka until the end of the war." Powers were given to local municipal and provincial administrative bodies to prohibit in their various localities "the sale of all strong drinks." These powers, it is reported, "have been largely exercised, and the Press daily report from all parts of the country the closure by local option of wine-shops, beersaloons, etc. In many places the prohibition is for all time, but in the majority of cases provisionally until the end of the year." Presumably, judging from the time the Memorandum was issued, the end of the year 1915 is meant. The Memorandum continues : " Other temperance measures which have been adopted are as follows: Numbers of beer-saloons and third-class eating and drinking houses in the towns of Russia have been compulsorily closed by order of local public bodies, with the sanction of the Government, and the number of streets in which the opening of such establishments is prohibited has been increased. The sale of all liquors has been forbidden in the vicinity of barracks, camps, military training areas, public market-places, and all the categories of educational establishments."

So far the Memorandum.

It would be an excellent thing if our military authorities would take similar action in regard to all "barracks, camps, and military training areas," in this country. An idea has unfortunately got abroad that any such suggestion implies a reflection upon our men in training, and that no such action is justified unless drunkenness and disorder are proved to exist. That is by no means an accurate view of the case. The prohibition is asked for in order, first, to promote the efficiency and physical wellbeing of the men upon whom, under God, our national safety depends. And secondly in order to prevent the possibility of drunkenness and disorder arising. But the stronger ground is the first-named, for no sensible man can argue at this time of day that alcohol as a beverage in any degree promotes physical efficiency.

What Russia has found it wise to do, and France has also in a measure felt it wise to do, is certainly worthy of our imitation. The testimony of Professor Pares, who is the official "Eyewitness" with the Russian armies, is most striking in its accounts of the physical fitness of the Russian soldiers. In a letter dated December 21, 1914, and issued by our Press Bureau on January 12, 1915, the Professor says: "The other main feature 
was the infinitely superior physique, spirit, and endurance, of the Russian soldiers, who have made wonderful marches, endured long periods of trench work on short food, and made remarkable recoveries from the most serious wounds." Their abstinence has not, therefore, reduced their value in the field. The Prime Minister stated in the House of Commons that 60 per cent. of our wounded men had been able to return to their duty. The returns of the Russian armies show, however, a recovery and return to duty of 85 per cent. of wounded, as was quoted in the last issue of the Journal. (p. 165). This difference of 25 per cent. is of enormous value in the present gigantic struggle. And when it is remembered that our medical supplies and services are in a much more efficient state than those of Russia, and can be brought into use much more promptly, the difference in percentage of recoveries is seen to be all the more significant.

In the second of his articles in The Times on "The Russian Army," Mr. Stanley Washburn bears testimony to the following effect: "One cannot write of the Russian mobilization, or of the rejuvenation of the Russian Empire, without touching on the prohibition of vodka. Those who knew Russia never dreamed that, when the lid was put on, it would be airtight, and the profoundest believers in prohibition never imagined how far-reaching would be the benefits. [I quote this expression of opinion without endorsing it.] The first manifest evidence of increased efficiency was, of course, in the manner and promptness with which the army assembled; but, from that day, the benefits have been increasingly visible, not only in the army, but in every phase of Russian life. At a time when money has been tight, the savings banks have enormously increased their deposits. Employers of labour state that the efficiency in services rendered will this year show an increased economic value to the Empire, which will offset the enormous loss of revenue. This statement is not susceptible of proof, but it is no doubt not far from the truth. Like everything in Russia, the law was somewhat slow in taking hold, but, after a month or two, it was difficult to get vodka in Petrograd. At the end of three months champagne and wines had disappeared, and now one cannot buy even a glass of beer in any hotel or restaurant in Russia that I know of. The most important effects, however, have been in the army. In nearly six months' association with the armies in many different theatres of operations I have not seen a single drunken or tipsy officer or soldier. This, then, 


\section{The British Journal of Inebriety}

was the first sign of what New Russia intended to do in this war. At one stroke she freed herself of the curse that has paralyzed her peasant life for generations. This in itself is nothing short of a revolution."*

Turning to another branch of the question, we find the remarkable effects upon the social and economic life of the people still continuing in undiminished degree. It is both a social revolution and a social regeneration which is being effected in Russia, and whilst one rejoices greatly at what has been thus far accomplished, one cannot restrain a feeling of envy when looking at our own stick-in-the-mud condition.

Mr. Frederick Rennet, Special Correspondent of the Daily News, wrote in that newspaper as follows : $\dagger$ " Since the prohibition of vodka, very many women who worked for their living have been paying as much as ten roubles (£1) a month to the Soldiers' Fund." Other correspondents have made similar statements. But the most remarkable testimony of all is that given by the Comptroller of the Treasury in his speech before the Budget Committee : "M. Kharitonoff, the Treasury Comptroller, speaking in the name of the Minister of Finance before the Budget Committee of the Duma to-day [January 25, 1915], said the cause of the present favourable economic conditions in Russia was no doubt the prohibition of the sale of spirits. As a proof of this he guoted statistics of the national savings, which in December, 1913, only amounted to $\$ 70,000$, as compared with $£ 2,910,000$ in December, 1914. In the first half of January, 1913, the figures were $£ 30,000$, as compared with $£ 1,530,000$ for the corresponding period this year. The total savings for 1913 amounted to $£ 3,400,000$, as against $£ 8,400,000$ in 1914 . These remarkable figures constitute an overwhelming proof of the unshakable power of Russia." $\ddagger$

The most encouraging feature of all is the way in which public opinion has endorsed the action of the Government. The people have risen to the height of self-sacrifice in the hour of their country's need, and even the confirmed drinkers are reported as saying that they willingly acquiesce in order to serve their country. Anything in the way of development and progress and

* The Times, March 5, 1915.

† Daily News, November 25, 1914.

I From Reuter, as published in The Times, January 26, 1915. 
victory is possible to a democracy which is capable of such things, and the results in many ways must be far greater than anyone can now foresee.

The Duma began its new session on February 9, 1915. The President, in his opening speech, referred to the prohibition of vodka in the following words: "Accept, great Monarch, the lowly reverence of thy people. Thy people firmly believe that an end has been put for all eternity to this ancient curse." According to The Times correspondent, at these words, "a scene of indescribable enthusiasm ensued, the House rising and singing the National Hymn." Later on the Prime Minister referred to the subject. The same correspondent thus reports his reference: "The Premier alluded to the tremendous change wrought in the national life by the abolition of the liquor traffic, which he designated a second serfdom vanishing at the behest of the Tsar."*

\section{ACTION IN FRANCE.}

According to such returns as are available, France is the most alcoholic nation in Europe, and therefore probably in the world. She has one licence to each eighty-two of her inhabitants. M. Joseph Reinach, the leader of the anti-alcohol party in the Chamber of Deputies, says that in the last sixty years the consumption of alcohol in France has increased to nearly six times the previous amount. Paris alone has over 30,000 places where liquor is sold. Several attempts have been made in recent years to secure some reduction in the facilities for the sale of alcohol, but they have always ended in failure; the interests were too strong. With the advent of the war, a new consciousness of the perils of alcoholism dawned upon the minds of the nation's leaders. It found expression first among the military men, and from them reached the politicians. Supreme national necessity demanded action from them in order to protect the army, and fortunately they had the courage to face the necessities of the case.

"At the beginning of the war, the Minister of the Interior sent a circular note to the Prefects of departments, 'inviting' them to suppress 'by order' the sale of and traffic in absinthe and kindred liquors. Such orders could only have effect during the war." $\dagger$

: See The Times, February 11, 1915.

$\dagger$ See communication from Paris correspondent in Daily News, January 9. 1915. 
Following upon this, the Minister of the Interior proposed two decrees, which President Poincaré signed early in January last, the one absolutely prohibiting the sale of absinthe and similar liquors, and the other making provision for a considerable reduction in the number of licensed houses. *

A Bill was founded upon the Absinthe Decree, and submitted to the Chamber of Deputies on February 12, 1915. This Bill made the prohibition of absinthe absolute for all time, and it was carried by 481 votes to $52 . \rightarrow$ Thus the "green fiend," as it has been called, the most powerful alcoholic beverage yet invented by the perverted ingenuity of man, disappears from the country of its origin, and, let us hope, also from those other countries into which it was beginning to be introduced, this country among the number.

Terrible as this war is, if one of its results is to abolish vodka in Russia and absinthe in France, it will have brought great blessings in its train. And if, as cynics and pessimists tell us, it is only a temporary prohibition which will soon be repealed when the war is over, yet even so a few months' freedom will teach valuable lessons and do an untold amount of good.

Once more we ask, When will this country follow the splendid example of her Allies?

"The Times, January 8, $1915 . \quad+$ lbid., February 13, 1915. 